\title{
EFFECT OF DIFFERENT IRRIGATION REGIME AND OLIVE VEGETATION WATER (OVW) TREATED WITH CYANOBACTERIA ON SOIL CHEMICAL PROPERTIES, GROWTH, YIELD AND FRUIT QUALITIES OF OLIVE TREES.
}

El-Taweel, A. A. ${ }^{1}$; A. A. Aly ${ }^{1}$ and Soha S.M. Mostafa ${ }^{2}$

${ }^{1}$ Department of Olive and Semi-Arid Zone Fruits, Horticulture Research Institute, Agricultural Research Center (ARC), Egypt.

${ }^{2}$ Department of Microbiology, Soils, Water and Environment Research Institute (SWERI), Agricultural Research Center (ARC), Egypt.

\begin{abstract}
The experiment was conducted during the two growing seasons of 2013 and 2014 on 13-year old Manzanillo olive trees in sandy loam soil, under drip irrigation system in a private farm located at $\mathrm{km} 50$ of Cairo-Alexandria road in the north west of Egypt. The trees are cultivated at $5 \times 8 \mathrm{~m}$. apart and grown under standard cultural practices. The objective of this study was to evaluate the effect of olive vegetation water (OVW) treated with mixed culture of cyanobacteria strains (Nostocmuscorum, Anabaena oryzae and Spirulina platensis) on Manzanillo olive trees under different irrigation levels and to highlight the economic advantages of these practices in improving fruit quality and crop yields. Processes to reduce the toxicity of OVW and make it acceptable for disposal onto soil or into receiving waters were reviewed. The effect of four treatments of different irrigation regime and olive vegetation water(OVW) with Cyanobacteria. Treaments were:a- control: 3400m3/feddan/year(100\%) b.3400m3/feddan/year(100\%)+2 liter OVW plus cyanobacteria was diluted in 22 liter of farmwater/tree, C$2550 \mathrm{~m} 3 /$ feddan/year $(75 \%)$ of the control+2 liter OVW plus cyanobacteria was diluted in 34 liter of farm water/tree, d$1700 \mathrm{~m} 3 /$ feddan/year $(50 \%)$ of the control +2 liter OVW plus cyanobacteria was diluted in 46 liter of farm water/tree. Data showed that application of irrigation at 100\% (irrigated with 2 liter/ tree of OVW plus Cyanobacteria) and diluted in 22 liter of farm water/tree and added in six months (January up to June) each two weeks gave the highest vegetative growth, flowering characteristics, yield and fruit oil content. Moreover, the same treatment significantly increased N, P, and Mn. This treatment would be recommended under this study and also under similar conditions and which confirmed by the economic study.

Keywords: Cyanobacteria, Olive Vegetation Water (OVW), irrigation
\end{abstract}

\section{INTRODUCTION}

Olive vegetation water $(\mathrm{OVW})$ is the liquid of by-product obtained during olive processing of extracting the virgin olive oil (Di-giovacchino et al., 2002). The disposal of waste water from olive oil extraction processes is a major and unresolved economic and environmental problem for olive oil producing countries such as those in Mediterranean areas. The mechanical extraction process of oil does not involve the addition of any inorganic or organic products, which could pollute the oil and the waste water derived from this process (Gamba et al., 2005). It can be assumed that the benefit of organic wastes recycling occurred only when they are applied according to best agronomical practices (Van-Camp et al., 2004). Many researchers have established that these wastes have a high value when applied to the soil (Garcia Barrionuevo et al., 1992 and Parades et al., 1999). However, the direct application to agricultural soils as organic fertilizers is the most frequently used method nowadays (Mekki et al., 2006) and also using OVW for irrigation offsets the water scarcity and low soil fertility in the Mediterranean region. Moreover, agricultural irrigation with waste water effluents became a common practice in arid and semiarid regions, where it was used as a readily available and inexpensive option to fresh water. Moreover, authors confirmed that the recycling of the OVW and its use as water for irrigation in agriculture provided that its impact on soil and plant was established as an attractive possibility for the Mediterranean countries (Mechri et al., 2007). In order to find convenient solutions for spreading this by-product into agricultural lands without harmful environmental effects, many studies were conducted in several olive producing oil countries (Casa et al., 2003 and El-Hadrami et al., 2004). Most of these studies were focused on the pretreatment of OVW using different microorganisms (Piperidou et al., 2000). Cyanobacteria or blue green algae (BGA) are photosynthetic $\mathrm{N}$ - fixers free microorganisms play a key role in improving growth of many plants when applied as bio-fertilizers (Sahu et al., 2012). Cyanobacteria considered the ideal solution for treating olive vegetative waste water (Amores-Sanchez et al., 2015). In the area of agriculture and horticulture, microalgae have been shown to stimulate the growth of plants, due to the presence of auxine, cytokinins, gibberellins and related growth regulator substances (Aly et al., 2008). In addition, cyanobacteria helped to save about $25 \%$ of irrigating water in calcareous soil and did not affect the productivity of crop yield (Mostafa et al., 2011). On the basis of these findings, this work built on to assess the benefits of reusing treated OVW via cyanobacteria as a bio fertirrigation, evaluate its influences on soil and olive trees and to highlight the economic advantages of these practices in improving fruit quality and crop yields under different water levels.

\section{MATERIALS AND METHODS}

\section{Field practices:}

The present study was carried out during 2013 and 2014 on Manzanillo olive trees grown in sandy soil. The trees were grown in a private orchard located at the Cairo-Alexandria desert road(about 50- Kilometer, Cairo). Considered trees were irrigated with deep well 
water using a bi-lateral drip irrigation system with 4 adjustable discharge emitters/tree. Water requirements were as following: November, December, January, February: two times/week(550 $\mathrm{m}^{3} /$ feddan); March, April, May, June: three times/week $\left(1100 \mathrm{~m}^{3 /}\right.$ feddan); July, August, September, October: six times/ week $\left(1750^{3} /\right.$ feddan). Total $=3400 \mathrm{~m}^{3} /$ fed. Variations in management were only in irrigation regimes which varied according to the experiment and conducted treatments. Variations were adjusted by emitter discharge without altering emitter's locations.

The olive waste water originates from a traditional process Cyanobacteria extract in tap water was applied in three rates $(24,36,48$ liters), each rate contains two liter of cyanobacteria.

Conventional management practices recommended by the Ministry of Agriculture were applied to all trees on equal bases. Farm fertilization (compost and mineral fertilization) were added at the second week of November and was applied in two parallel ditches of $100 \times 40 \times 30 \mathrm{~cm}$, for length, width and depth respectively. The ditches surrounded th tree from two direction in the end of canopy shade. The amount of compost was $50 \mathrm{Kg} /$ tree. the rate of mineral fertilization was $100 \mathrm{gm}$ nitrogen $+270 \mathrm{gm}$ potassium $+0.5 \mathrm{Kg}$ of $\mathrm{MgSO}_{4}(9.6 \% \mathrm{Mg})+0.25 \mathrm{Kg}$ as sulphur $+0.25 \mathrm{Kg}$ Boron per tree.

The experiment consisted of 4 treatments; replicated 3 times in a randomized block design.

The selected experiment trees were nearly uniform and vigor growth and free from pathological and physiological disorders received the same culture management (irrigation, weed, pests, and diseases control usually applied in the orchard except for the irrigation treatments).

\section{The treatments involved:}

a. Control of irrigated at $100 \%$ only (four drippers under the canopy of the trees and each one received 8 liter/hour per tree (total 32 liter/ hour/tree), that mean 3400m3/feddan/year.

b. Application of irrigated at $100 \%$ with 24 liter/ tree of OVW plus Cyanobacteria (four drippers without blocked irrigated), that mean $3400 \mathrm{~m} 3 /$ feddan/year(diluted in 22 liter of farm water/tree).

c. Application of irrigated $75 \%$ with 36 liter/tree of OVW plus Cyanobacteria (one drippers were blocked under the trees irrigated), that mean ( $2550 \mathrm{~m} 3 /$ feddan/year(diluted in 34 liter of farm water/tree).

d. Application of irrigated 50\% with 48 liter/tree of OVW plus Cyano bacteria (two drippers was blocked under the trees irrigated), that mean $(1700 \mathrm{~m} 3 /$ feddan/year(diluted in 46 liter of farm water/tree).

e. Three application of the olive oil vegetable water were used, were add to each tree at the end of canopy shade each two weeks during the period from the first of January till the end of fruit set.

2-Soil, olive vegetable water (OVW), water samples and compost:

Soil samples were randomly collected from the zone of the end of root ramification of the canopy in
November. Depth of the soil sampling was $0-60 \mathrm{~cm}$. (Fernandez Je et al., 1991). Soil texture characterization and chemical analyses were determined according to the methods described by (Page et al. 1982) as shown in Table (1). Analysis of the tested olive vegetable water is shown in Table (2). Samples of irrigation water and compost were collected during the experiment and analyzed as shown in Table (3) and Table (4).

\section{3- Soil measurements \\ Soil enzymes activity}

Fresh soil samples of the root zone were tested for dehydrogenase (Casida et al., 1964) and nitrogenase (Hardy et al., 1973) enzymes activity two weeks after the last biological treatments dose application.

\section{Soil chemical analyses}

Air dried soil samples were ground to pass through a $2 \mathrm{~mm}$ sieve using a wooden grinding and stored in plastic bottles prior to the physical and chemical analysis.

Available nitrogen in soil was determined according to the method described by (Black et al. 1982). Available phosphorus was determined spectrophotometrically as mentioned by Watanabe and Olsen (1965). Available potassium was determined using flame-photometric method (Black et al., 1982). Microelements ( $\mathrm{Fe}, \mathrm{Mn}$ and $\mathrm{Zn}$ ) were extracted using DPTA (Lindsay et al., 1954). Soil reaction (pH) was measured in 1:2.5 soil water extract using glass electrode $\mathrm{pH}$ meter Model (955), and electric conductivity (EC) was measured in 1:5 soil water extract using glass electrode conductivity meter Model Jenway 4310. Soil organic matter (O.M \%) was determined using potassium dichromate (Chapman and Pratt, 1961). Phenolic compounds from the soil samples were extracted with ethyl-acetate. The soil phenols were extracted with ethyl-acetate using a ratio of $5: 1(\mathrm{v} / \mathrm{w})$ and total phenol was determined by Folin-Ciocalteau colorimetric method using Gallic acid as a standard (Box, 1983).

\section{Olive vegetable water (OVW)}

Olive vegetable water (OVW) was obtained from a private farm located at km50 of Cairo-Alexandria, Egypt. The raw OVW was generated by the three-phase olive-oil extraction process and was left to settle for $24 \mathrm{hr}$. then; the light supernatant after the sedimentation was filtered by passing through a sieve (mesh size about $200 \mu$ ) and was kept to be used as substrate for cyanobacteria cultivation. Physical and chemical properties of OVW obtained from olive oil three phase extraction mill collected during the late fall and winter season was determined at Soil and Water Research Institute (SWERI), Agricultural Research Centre (ARC). Physical and chemical properties of OVW obtained from olive oil three phase extraction mill collected during the late fall and winter season was determined at Soils, Water and Environment Research Institute (SWERI), Agricultural Research Centre (ARC), Egypt. 
Table1. Physical and chemical characteristics of the testing soil

\begin{tabular}{lcc}
\hline Character & 2013 & 2014 \\
\hline Particles size distribution & 5.45 & 5.41 \\
Coarse sand (\%) & 76.35 & 78.00 \\
Fine sand (\%) & 12.9 & 11.08 \\
Silt (\%) & 6.30 & 5.51 \\
Clay (\%) & Loamy sand & Loamy sand \\
Texture & & 4.30 \\
Chemical analysis & 4.40 & 8.10 \\
EC dS/m $(1: 2.5)$ & 8.46 & 0.26 \\
pH (1:2:5) & 0.18 & 0.15 \\
Organic matter (\%) & 0.11 & 0.22 \\
Organic carbon $(\%)$ & & 0.50 \\
Total nutrients mg/100g & 0.13 & 16.82 \\
N & 0.40 & 1.90 \\
P & 7.40 & 0.61 \\
Total nutrients $\mathrm{mg} / \mathrm{kg}$ & & 1.82 \\
Mn & 1.35 & 0.46 \\
Fn & 1.60 & \\
\hline
\end{tabular}

Before the application of the treatments, a compost sample was taken and analyzed at Soils, Water and Environment Research Institute (SWERI), Agricultural Research Centre (ARC), Egypt and illustrated in Table(4).

Table 2. Chemical analysis of OVW samples (Values are average of two seasons)

\begin{tabular}{|c|c|c|c|}
\hline \multirow{2}{*}{$\frac{\text { Parameters }}{\mathrm{pH}(1: 2.5)}$} & \multirow{2}{*}{$\begin{array}{c}\text { Olive Vegetative water } \\
5.01\end{array}$} & \multicolumn{2}{|c|}{$\begin{array}{l}\text { Olive vegetative water treated with } \\
\text { cyanobacteria }\end{array}$} \\
\hline & & \multicolumn{2}{|c|}{8.00} \\
\hline $\mathrm{EC} \mathrm{ds} / \mathrm{cm}$ & 5.52 & \multicolumn{2}{|c|}{3.10} \\
\hline Total nitrogen (\%) & 1.10 & \multicolumn{2}{|c|}{3.10} \\
\hline Organic Matter (\%) & 20.81 & \multicolumn{2}{|c|}{2.80} \\
\hline Organic carbon (\%) & 12.10 & \multicolumn{2}{|c|}{1.04} \\
\hline Total phenols (\%) & 0.80 & \multicolumn{2}{|c|}{0.28} \\
\hline $\mathrm{C} / \mathrm{N}$ ratio & 8.64 & \multicolumn{2}{|c|}{0.45} \\
\hline Total P (\%) & 0.60 & \multicolumn{2}{|c|}{1.90} \\
\hline Total K (\%) & 1.30 & \multicolumn{2}{|c|}{2.50} \\
\hline $\mathrm{N}-\mathrm{NH}_{4}(\mathrm{ppm})$ & 25.50 & \multicolumn{2}{|c|}{ T.A.N. $(p p m)^{*}$} \\
\hline $\mathrm{N}-\mathrm{NO}_{3}(\mathrm{ppm})$ & 8.90 & \multicolumn{2}{|c|}{2002.00} \\
\hline \multicolumn{4}{|c|}{ *T.A.N. = total available nitrogen. } \\
\hline Parameter & Value & Parameter & Value \\
\hline $\mathrm{EC}(\mathrm{dS} / \mathrm{m})$ & 1.53 & Hard soluble $\mathrm{Mg}$ & 50 \\
\hline SAR & 4.10 & $\mathrm{Mg}$ & 12.15 \\
\hline $\mathrm{pH}$ & 7.26 & $\mathrm{Na}$ & 313 \\
\hline ppm & & $\mathrm{K}$ & 7.52 \\
\hline $\mathrm{NO}_{3}$ & Non & $\mathrm{Fe}$ & 1.02 \\
\hline $\mathrm{Po}_{4}$ & 0.80 & $\mathrm{Mn}$ & 0.24 \\
\hline $\mathrm{Cl}$ & 147 & $\mathrm{Zn}$ & 0.14 \\
\hline Phenols & Non & $\mathrm{Cu}$ & 0.07 \\
\hline $\mathrm{Ca}$ & 123 & B & 0.05 \\
\hline
\end{tabular}

Table 4. Physical and chemical analysis of compost

\begin{tabular}{lccc}
\hline Parameter & Value & Parameter & Value \\
\hline $\mathrm{pH}(1: 2.5)$ & 9.01 & Total P $(\%)$ & 0.54 \\
$\mathrm{EC}(\%)$ & 7.89 & Total K $(\%)$ & 2.64 \\
$\mathrm{TN}(\%)$ & 1.95 & $\mathrm{~N} \mathrm{NH}(\mathrm{ppm})$ & 657.9 \\
Organic carbon $(\%)$ & 28.50 & $\mathrm{~N} \mathrm{No}_{3}(\mathrm{ppm})$ & 152.9 \\
C/N ratio & 14.62 & & \\
Organic matter $(\%)$ & 49.02 & & \\
\hline
\end{tabular}




\section{4- Cyanobacteria source and growth conditions:}

Three cyanobacteria strains (Nostocmuscorum, Anabaena oryzae and Spirulinaplatensis) were obtained from the Microbiology Department; Soils, Water and Environment Research Institute (SWERI), Agricultural Research Center (ARC), Giza, Egypt. $\mathrm{N}_{2}$-fixing strains (Nostocmuscorum and Anabaena oryzae) were maintained separately on BG11 medium (Rippka et al., 1979). While, the non $\mathrm{N}_{2}$-fixing alga Spirulinaplatensis was grown on Zarrouk medium (Zarrouk, 1966). Cultures were incubated in growth chamber under continuous shaking (150 rpm) and illumination (2000 lux) at $27{ }^{\circ} \mathrm{C} \pm 2{ }^{\circ} \mathrm{C}$ for 30 days to be used as inoculums for lab experiment.

\section{5- Biofertilizer production for field experiment:}

Fifty-liter plastic tanks were used to prepare Cyano-OVW biofertilizer by diluting non sterilized OVW with tap water $(1: 1 \mathrm{v} / \mathrm{v})$. Tanks were under continuous aeration for two days by air pumps before cyanobacterial inoculation. Ten $\mathrm{L}$ of cyanobacterial mixed culture at $\log$ phase $(1: 1: 1 \mathrm{v} / \mathrm{v})$ were added to $40 \mathrm{~L}$ of 1:1 OVW tap water diluted and incubated for two weeks under lab. conditions and continuous aeration to be used for field experiments.

\section{6- Measurements:}

\section{Vegetative growth parameters}

At the end of each growing season during first week of August the following characteristics were measured:

a. Number of leaves per shoot.

b. Average shoots length $(\mathrm{cm})$.

c. Leaf area $\left(\mathrm{cm}^{2}\right)$ : using a planimeter according to Aly (2005).

\section{Leaf minerals and phenols contents:}

At the first week of August of each season, leaf samples were taken from mid of the current of growing shoot (Piper, 1950) and then water washed; air dried at $70^{\circ} \mathrm{C}$ till constant weight and finally grounded. Thereafter the following determinations were carried out in the acid digested solutions as reported by Van Shouwenburg (1968).

- Nitrogen was determined by the Micro kjeldahl method (Pregl, 1945).

- Phosphorous was estimated by the method described by Murphy and Riely (1962)

- Potassium was flame-photometerically determined according to the method described by (Brown and Lilleland, 1946).

- Calcium was flame-spectrometerically determined according to the method described by Chapman and Partt, (1961)

- Microelements (Fe, Mn, Zn, Cu) as ppm was spectrophotometerically determined using atomic absorption (Model, spectonic 21D) as the method described by Jackson (1973).

- Total phenolic compounds were determined using the Folin-Ciocalteu reagent method (Skerget et al., 2005)

\section{Flowering parameters:}

\section{a. Inflorescence length $(\mathbf{c m})$ :}

Thirty inflorescences were randomly taken from each replicate and the length of their axis was measured. b- Flowering density: number of inflorescence per meter on the labeled twenty shoots were calculated. It was calculated by the following formula.

Flowering density (FD) $=$ (av. No. of inflorescences/ Av. Shoot length $(\mathrm{cm}) * 100$

c. Average number of total flowers per Inflorescence

Samples of 30 inflorescences (located in inner and outer portions of the tree) were taken from the middle portions of shoots and the total number of flowers per inflorescence were counted and tabulated.

\section{d. Percentage of perfect flowers}

Twenty inflorescences at balloon stage were collected from the middle portions of shoots from each tree. The percentage of perfect flowers to the total number of flowers was calculated.

The perfect flowers $\%=$ No. of perfect flowers/No. of total flowers x 100

\section{Fruiting (fruit set and yield)}

Number of fruitless tagged on each replicate was recorded after 60 days from full bloom according to (Mofeed, 2002).

Percentage of Initial fruit set was calculated according to the following equation.

Initial fruit set $(\%)=$ (Total number of fruitless/total number of perfect flowers)

$* 100$.

a. Yield:

At the stage of green maturity fruits from each considered tree were picked, then weighed in $\mathrm{Kg}$ and counted and recorded.

Fruits and Stones characterizes:

b- Fruits:

Fifty fruits per each tree at maturity were randomly selected in both seasons, from each replicate to study different physical and chemical characteristics of fruit in different treatments according to the following basis:

- Fruit characters:

- Fruit length $(\mathrm{cm})$.

- Fruit diameter $(\mathrm{cm})$

- Fruit weight(gm).

c- Stones:

- Stones were extracted from the selected fruits to determine the following physical characteristics:- stone length $(\mathrm{cm})$, Stone diameter $(\mathrm{cm})$ and stone weight $(\mathrm{g})$.

Flesh/fruit weight percentage was calculated according to the following equation.

Flesh weight $=$ average fruit weight- average stone weight $(\mathrm{g})$ The flesh/fruit $(\%)=$ Flesh weight/ average fruit weight x100 according to Fouad et al. (1992).

Fruit oil content (\%)

Fruit oil content as a dry weight was determined according to (AOAC, 1995) method by extraction the oil from the dried fruits with soxelt fat extraction apparatus using petroleum ether $60-80^{\circ} \mathrm{C}$ of boiling point.

\section{7- Economic evaluation:}

Economic evaluation was calculated according to

Heady and Dillon (1961) as follows:

- Total gross income $=$ total yield $(\mathrm{kg}) \times 3 \mathrm{~L} . \mathrm{E}$.

- Gross margin= total gross income-total cost. 
Annual applied water quantities/fed of control was 3400 $\mathrm{m}^{3} /$ feddan.

\section{8- Statistical analysis:}

The obtained data was subjected to the method described by analysis of variance (ANOVA) according to (Snedecor and Cochran, 1980). Differences between treatments were compared by Duncan's multiple range tests SAS (SAS, 1994).

\section{RESULTS AND DISCUSSION}

\section{1- Soil enzymes:}

\section{Effect of different irrigation regime with Cyanobacteria} and $(\mathrm{OVW})$ on soil enzymes:

Results in Table (5) showed that all irrigation levels that received Cyanobacteria + OVW biofertilizers increased soil enzymes activity in terms of dehydrogenase and nitrogenase even with $50 \%$ reduction of irrigation water over than control in both studded seasons. The highest significant values (3.39 \& 3.50 and $491.45 \& 498.68)$ in both seasons, respectively recorded with received $100 \%$ irrigated plus Cyanobacteria with 24 liters/tree of OVW. These results indicated that the produced biofertilizer stimulate total soil microorganisms as well as the $\mathrm{N}_{2}$-fixers. Cyanobacteria have emerged as promising detoxification microorganism Degradation of diversehazardous contaminants, synthesis of high-value secondary metabolites, use of sunlight as energy source, production of photosynthetic oxygen that reduces the need for external aeration, are advantages that render these microorganisms as attractive "pollutant removers "(Amores-Sanchez et al., 2015). These results are compatible with that reported by Piotrowska et al. (2006) and are in accordance with many previous works like by Gamba et al. (2005) and Ibrahim et al. (2007) and Magdich et al. (2012).

Table 5. Effect of different irrigation regime and OVW treated with Cyanobacteria on soil enzymes activity during seasons of 2013 and 2014.

\begin{tabular}{|c|c|c|c|c|}
\hline \multirow{2}{*}{ Treatments } & \multicolumn{2}{|c|}{ Dehydrogenase ( $\mu$ gTPF.g.$^{-1}$ dry soil) } & \multicolumn{2}{|c|}{ Nitrogenase $\left(\mu\right.$ mol $\left.C_{2} H_{4} \cdot g^{-1} \cdot h^{-1}\right)$} \\
\hline & 2013 & 2014 & 2013 & 2014 \\
\hline Control (100\%) Irrig. & $0.67 \mathrm{C}$ & $0.70 \mathrm{D}$ & $13.70 \mathrm{D}$ & $14.60 \mathrm{D}$ \\
\hline $\mathrm{I}_{1} 100 \%$ Irrig. + OVW +Cy. Ba. & $3.39 \mathrm{~A}$ & $3.50 \mathrm{~A}$ & $491.45 \mathrm{~A}$ & $498.68 \mathrm{~A}$ \\
\hline $\mathrm{I}_{2} 75 \%$ Irrig. + OVW +Cy. Ba & $1.14 \mathrm{~B}$ & $1.26 \mathrm{~B}$ & $79.86 \mathrm{~B}$ & $91.89 \mathrm{~B}$ \\
\hline $\mathrm{I}_{3} 50 \%$ Irrig. $+\mathrm{OVW}+\mathrm{Cy} . \mathrm{Ba}$ & $0.85 \mathrm{C}$ & $0.92 \mathrm{C}$ & $43.08 \mathrm{C}$ & $51.97 \mathrm{C}$ \\
\hline
\end{tabular}

$\mathrm{I}=$ irrigation $\mathrm{Cy} \cdot \mathrm{Ba}=$ Cyanobacteria

OVW = olive vegetation water

Means having the same letter(s) within the same column are not significantly differ at the probability of $5 \%$ level according to Duncan's Multiple Range Test.

\section{2- Chemical properties}

Effect of different irrigation regime and OVW with Cyanobacteria on soil chemical properties

Data in Table (6) showed that all irrigation levels that received Cyanobacteria + OVW biofertilizer increased the availability and total soil contents of $\mathrm{N}, \mathrm{P}, \mathrm{K}, \mathrm{Fe}$ and $\mathrm{Zn}$ as compared with control in both seasons. Applications of irrigation levels that received Cyanobacteria + OVW biofertilizer had insignificant effect on $\mathrm{pH}$ values in the first season. Regarding the second season, the $\mathrm{pH}$ values significantly decreased by treatments received $100 \%$ irrigated plus Cyanobacteria with 24 liter/tree of OVW comparing with other irrigation levels. On the other hand, the decrease in $\mathrm{pH}$ values in the second season was due to the reduction of water irrigation at the rates of $25-50 \%$ in treatments that received 36 and $48 \mathrm{~L} /$ tree (Table 6).

The decrease of $\mathrm{pH}$ could be due to the degradation of some phenolic acids present in the waste. The level of $\mathrm{pH}$ reached at the end of the process $(7.84-7.91)$ was suitable for the microbial growth. The increase in the soil salinity could result from the main ionic species, sodium chloride and sulphate, which came from the treated or untreated OVW. The OVW also has a high potassium concentration and not able levels of phosphorus, calcium, magnesium and iron (Parades et al, 1999).

The enhancement of organic and mineral nutrient contents might have a beneficial effect on soil fertility. The increase in $\mathrm{C} / \mathrm{N}$ ratio (Table 6) in both seasons reflected the increase in nitrogen fixation by cyanobacteria (Chartzoulakis et al. 2010 and Sahu et al., 2012) showed that after 3 years of raw OVW application, there were no significant differences in $\mathrm{pH}$, electrical conductivity (EC), $\mathrm{P}, \mathrm{Na}$ and organic rates between the control and OVW treated soils. Further, advantage of OVW is the increase of soil aggregate stability (Mahmoud et al., 2012).

The phenolic compound concentration in plant and soil amended with 24, 36 and $48 \mathrm{~L} /$ tree of cyanobacteria + OVW biofertilizer under different irrigation levels are shown in Table (7). Regarding, total phenols in leaves, all treatments were lower than control in both seasons. This reduction of total phenols in soil treated with cyanobacteria + OVW could be due to the biodegradation ability of cyanobacteria to phenolic compounds (Amores-Sanchez et al., 2015).

OVW organic matter and contained residues of oil and grease form a coating on soil aggregates and pore walls, which may reduce anion diffusion into soil aggregates. OVW has a beneficial influence on soil aggregation, soil structure stability and hydrodynamic properties of a sandy soil. Thus, land application of OVW can be sustainable and cost-effective recycling of nutrients and organic matter of this effluent to soil (Mohawesh et al., 2014) 
Table (6): Effect of different irrigation regime and OVW treated with Cyanobacteria on soil chemical properties during seasons of 2013 and 2014.

\begin{tabular}{|c|c|c|c|c|c|c|c|c|c|c|c|c|}
\hline \multirow{2}{*}{ Treatments } & \multicolumn{3}{|c|}{ Total $(\%)$} & \multicolumn{3}{|c|}{ Available (mg/kg) } & \multicolumn{3}{|c|}{ Available (mg/kg) } & \multirow[b]{2}{*}{$\mathbf{p H}$} & \multirow[b]{2}{*}{ EC } & \multirow{2}{*}{ ОС\% ОМ\% } \\
\hline & $\mathbf{N}$ & $\mathbf{P}$ & $\mathbf{K}$ & $\mathbf{N}$ & $\mathbf{P}$ & $\mathbf{K}$ & Mn & Zn & $\mathbf{F e}$ & & & \\
\hline
\end{tabular}

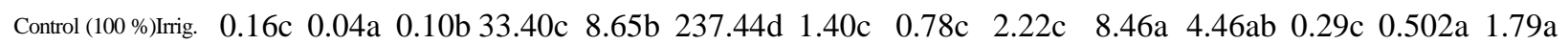

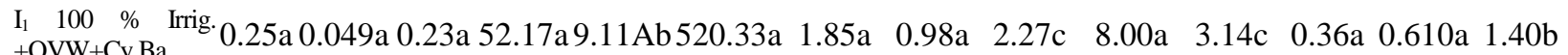

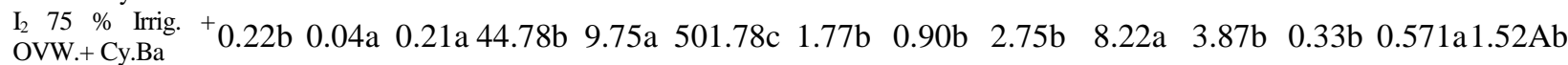

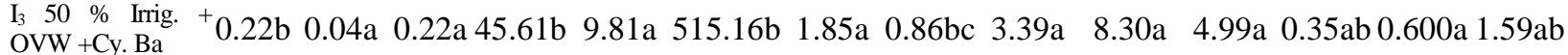
Season of 2014

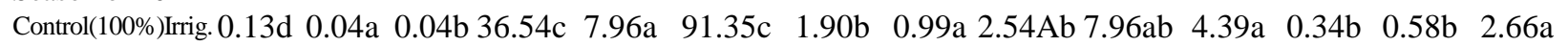

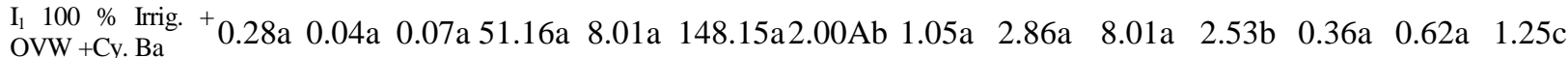

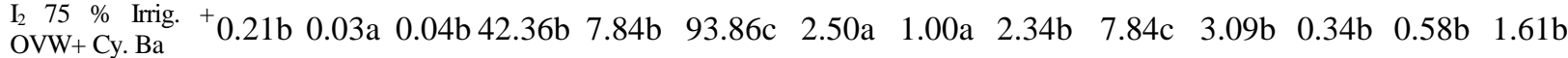

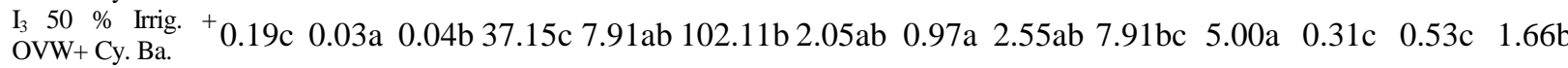

$\mathrm{I}=$ irrigation

Cy.Ba $=$ Cyanobacteria

OVW = olive vegetation water

Means having the same letter(s) within the same column are not significantly differ at the probability of $5 \%$ level according to Duncan's Multiple Range Test.

Table 7. Effect of different irrigation regime and OVW treated with Cyanobacteria on total phenolic contents of soil and olive leaves during seasons of 2013 and 2014

\begin{tabular}{|c|c|c|c|c|}
\hline \multirow[t]{2}{*}{ Treatments } & \multicolumn{2}{|c|}{$\begin{array}{l}\text { Total phenols in leaves } \\
\left(\mathrm{mg} * \mathrm{GAE} \mathrm{g}^{-1} \mathrm{DM}\right)\end{array}$} & \multicolumn{2}{|c|}{$\begin{array}{l}\text { Total phenols in soil } \\
\left(\mathrm{mg} * \mathrm{GAE} \mathrm{g}^{-1} \mathrm{DM}\right)\end{array}$} \\
\hline & 2013 & 2014 & 2013 & 2014 \\
\hline Control (100 \%) Irrig. & $25.50 \mathrm{a}$ & $28.00 \mathrm{a}$ & $82.69 \mathrm{a}$ & $76.02 \mathrm{a}$ \\
\hline $\mathrm{I}_{1} 100 \%$ Irrig. + OVW +Cy. Ba. & $20.66 c$ & $16.40 \mathrm{c}$ & $59.66 b$ & $46.43 b$ \\
\hline $\mathrm{I}_{2} 75 \%$ Irrig. + OVW +Cy. Ba. & $13.89 \mathrm{~d}$ & $21.74 b$ & $57.04 \mathrm{c}$ & $55.31 \mathrm{c}$ \\
\hline $\mathrm{I}_{3} 50 \%$ Irrig. + OVW +Cy. Ba. & $22.99 b$ & $22.58 b$ & $54.63 d$ & $53.93 d$ \\
\hline $\mathrm{I}=$ irrigation & \multicolumn{2}{|c|}{ Cy.Ba $=$ Cyanobacteria } & \multicolumn{2}{|c|}{$\mathrm{OVW}=$ olive vegetation water } \\
\hline
\end{tabular}

Means having the same letter(s) within the same column are not significantly differ at the probability of $5 \%$ level according to Duncan's Multiple Range Test.

\section{3- Vegetative growth parameters}

Effect of different irrigation regime and OVW with treated Cyanobacteria on vegetative growth parameters

Data in Table (8) depict the effect of applications of OVW plus cyanobacteria with three concentrations (24 L/tree, $36 \mathrm{~L} /$ tree and $48 \mathrm{~L} /$ tree) on some growth parameters. In this concern application of $100 \%$ irrigated plus cyanobacteria with 24 liter/tree of OVW presented the highest significant No. of leaves $(24.21 \&$ $25.00)$, shoot length (24.10 \& 25.50) and leaf area (3.84 $\& 3.93$ ) in both seasons, respectively.
This may be ascribed to the synergistic effect of organic matter as expected; the organic treatments produced better quality plants with respect to control (Shereen et al., 2011). The previous results are in agreement with those obtained by Mechri et al. (2007), who reported that recycling of the OVW and its use as water for irrigation in agriculture provided its impact on soil and plant. Also, several studies have shown that biofertilizers affected soil properties. Through its contents of different strains of a symbiotic associative diazotrophes, solubilizing microorganisms of phosphate, silicate dissolving microorganisms (Saber, 1993; Baradi and Malusa, 2012).

Table 8. Effect of different irrigation regime and OVW treated with Cyanobacteria on vegetative growth of Manzanillo olive leaves during 2013 and2014 seasons

\begin{tabular}{lcccccc}
\hline \multirow{2}{*}{ Treatments } & \multicolumn{2}{c}{ No. of leaves } & \multicolumn{2}{c}{ Shoot length } & \multicolumn{2}{c}{ Leaf area } \\
& $\mathbf{2 0 1 3}$ & $\mathbf{2 0 1 4}$ & $\mathbf{2 0 1 3}$ & $\mathbf{2 0 1 4}$ & $\mathbf{2 0 1 3}$ & $\mathbf{2 0 1 4}$ \\
\hline Control (100\%) Irrig. & $15.65 \mathrm{~d}$ & $16.00 \mathrm{c}$ & $17.20 \mathrm{c}$ & $19.73 \mathrm{c}$ & $2.34 \mathrm{c}$ & $2.58 \mathrm{c}$ \\
$\mathrm{I}_{1} 100 \%$ Irrig. + OVW +Cy. Ba. & $24.21 \mathrm{a}$ & $25.00 \mathrm{a}$ & $24.10 \mathrm{a}$ & $25.50 \mathrm{a}$ & $3.84 \mathrm{a}$ & $3.93 \mathrm{a}$ \\
$\mathrm{I}_{2} 75 \%$ Irrig. + OVW +Cy. Ba. & $20.76 \mathrm{~b}$ & $20.90 \mathrm{~b}$ & $18.90 \mathrm{~b}$ & $22.13 \mathrm{~b}$ & $3.06 \mathrm{~b}$ & $3.15 \mathrm{~b}$ \\
$\mathrm{I}_{3}$ 50\% Irrig. + OVW +Cy. Ba. & $18.69 \mathrm{c}$ & $15.57 \mathrm{~d}$ & $14.70 \mathrm{~d}$ & $16.47 \mathrm{~d}$ & $2.04 \mathrm{~d}$ & $2.23 \mathrm{~d}$
\end{tabular}

$\mathrm{I}=$ irrigation $\quad$ Cy.Ba $=$ Cyanobacteria $\quad$ OVW $=$ olive vegetation water

Means having the same letter(s) within the same column are not significantly differ at the probability of $5 \%$ level according to Duncan's Multiple Range Test. 
4- Leaf mineral contents:

Effect of different irrigation regime and OVW with Cyanobacteria on leaf mineral contents:

Data in Table (9) showed that application of $100 \%$ irrigated plus cyanobacteria with liter/tree of OVW raised up the macro nutrients in leaves of Manzanillo olive trees compared to untreated control in both seasons. The highest nitrogen and phosphorus percent in leaves $(1.41 \& 1.43 \%$ and $0.82 \& 0.86 \%$, respectively) obtained for treatment of $100 \%$ irrigated plus cyanobacteria with 24 liter/tree of OVW, while the highest values of potassium content $(1.52$ and $1.56 \%$ ) recorded for $75 \%$.

liter/tree of OVW in the first and second seasons, respectively. Concerning micronutrients in leaves, results cleared that the application of $100 \%$ irrigated plus cyanobacteria with 24 liter/tree of OVW was the superior treatment increase of $\mathrm{Mn}$ (24.23 and $25.07 \mathrm{ppm}$ ) in 2013 and 2014 seasons, respectively. Regarding the $\mathrm{Zn}$ and $\mathrm{Fe}$ the untreated control gave the highest values $(48.57 \& 48.80 \mathrm{ppm}$ and $120.30 \& 128.20 \mathrm{ppm}$ ) in both seasons, respectively.

These increases are related to improving soil quality, as a result of a rising organic matter content of OVW and an enrichment in N2- fixing bacteria which is a very important factor for soil fertility (Lopez et al., 1996). Recently, Bardi and Malusa (2012) mentioned that the positive influence of rhizosphere microorganisms on nutrient uptake is well established. The previous results agree with those obtained by Montemurro et al. (2011) and Lozano et al. (2013).

Table 9. Effect of different irrigation regime and OVW treated with Cyanobacteria on some macro and micro elements of Manzanillo olive leaves during 2013 and2014 seasons

\begin{tabular}{|c|c|c|c|c|c|c|}
\hline Treatments & $\mathbf{N}(\%)$ & $\mathbf{P}(\%)$ & $\mathrm{K}(\%)$ & Mn (ppm) & Zn (ppm) & Fe (ppm) \\
\hline \multicolumn{7}{|l|}{ Season of 2013} \\
\hline Control $(100 \%)$ & $1.10 \mathrm{c}$ & $0.70 \mathrm{bc}$ & $1.22 \mathrm{c}$ & $13.50 \mathrm{~d}$ & $48.57 \mathrm{a}$ & $120.30 \mathrm{a}$ \\
\hline $\mathrm{I}_{1} 100 \%$ Irrig. + OVW +Cy. Ba. & $1.41 \mathrm{a}$ & $0.82 \mathrm{a}$ & $1.39 \mathrm{~b}$ & $24.23 \mathrm{a}$ & $39.80 \mathrm{c}$ & $105.30 \mathrm{~d}$ \\
\hline $\mathrm{I}_{2} 75 \%$ Irrig. + OVW +Cy. Ba. & $1.27 \mathrm{~b}$ & $0.64 \mathrm{c}$ & $1.52 \mathrm{a}$ & $21.30 \mathrm{~b}$ & $43.10 \mathrm{~b}$ & $109.80 \mathrm{c}$ \\
\hline $\begin{array}{l}\mathrm{I}_{3} 50 \% \text { Irrig. }+ \text { OVW +Cy. Ba. } \\
\text { Season of } 2014\end{array}$ & $1.00 \mathrm{c}$ & $0.72 b$ & $1.27 \mathrm{c}$ & $17.10 \mathrm{c}$ & $39.07 d$ & $115.30 \mathrm{~b}$ \\
\hline Control $(100 \%)$ & $1.15 \mathrm{c}$ & $0.71 \mathrm{c}$ & $1.27 \mathrm{~d}$ & $16.63 d$ & $48.80 \mathrm{a}$ & $128.20 \mathrm{a}$ \\
\hline $\mathrm{I}_{1} 100 \%+\mathrm{OVW}+\mathrm{Cy} . \mathrm{Ba}$. & $1.43 \mathrm{a}$ & $0.86 \mathrm{a}$ & $1.44 b$ & $25.07 \mathrm{a}$ & $45.07 \mathrm{c}$ & $108.40 d$ \\
\hline $\mathrm{I}_{2} 75 \%+\mathrm{OVW}+\mathrm{Cy} . \mathrm{Ba}$ & $1.30 \mathrm{~b}$ & $0.68 \mathrm{~d}$ & $1.56 \mathrm{a}$ & $22.70 b$ & $48.50 \mathrm{~b}$ & $115.40 \mathrm{c}$ \\
\hline $\mathrm{I}_{3} 50 \%+$ OVW +Cy. Ba. & $1.09 \mathrm{c}$ & $0.74 b$ & $1.34 \mathrm{c}$ & $19.00 \mathrm{c}$ & $41.47 \mathrm{~d}$ & $118.65 b$ \\
\hline $\mathrm{I}=$ irrigation & \multicolumn{2}{|c|}{ Cy.Ba = Cyanobacteria } & \multicolumn{4}{|c|}{ OVW $=$ olive vegetation water } \\
\hline
\end{tabular}

Means having the same letter(s) within the same column are not significantly differ at the probability of $5 \%$ level according to Duncan's Multiple Range Test.

\section{5- Flowering parameters}

Effect of different irrigation regime and OVW with Cyanobacteria on flowering parameters:

Table (10) shows the effect of different irrigation regime and OVW with cyanobacteria on flowering parameters (Length. of inflorescences $(\mathrm{cm})$, flowering density, No. of total flowers/ infl. and perfect flower percentage). These parameters affected the aforementioned treatments compared to the control in both seasons. The application of $100 \%$ irrigation plus Cyanobacteria +
OVW (24 liter/tree) gave the highest significant values comparing to other treatments in both seasons. (Kulk 1995 and Adam 1999) reported that the growth promotion in response to application of nitrogen fixer cyanobacterium (Nostocmuscom) could be attributed to the nitrogenase as well as nitrate reductase activities of algae associated with the surface of plants, or the amino acids and peptides produced in algal filtrate and / or other compounds that stimulated growth of crop plants.

Table 10.Effect of different irrigation regime and OVW treated with Cyanobacteria on flowering parameters of Manzanillo olive leaves during 2013 and2014 seasons

\begin{tabular}{lcccccccc}
\hline \multirow{2}{*}{ Treatments } & \multicolumn{2}{c}{ Length of } & \multicolumn{2}{c}{ Flowering density } & \multicolumn{2}{c}{ No. of total flowers/infl. } & \multicolumn{2}{c}{ Perfect flowers \% } \\
& $\mathbf{2 0 1 3}$ & $\mathbf{2 0 1 4}$ & $\mathbf{2 0 1 3}$ & $\mathbf{2 0 1 4}$ & $\mathbf{2 0 1 3}$ & $\mathbf{2 0 1 4}$ & $\mathbf{2 0 1 3}$ & $\mathbf{2 0 1 4}$ \\
\hline Control (100 \%) & $1.80 \mathrm{c}$ & $2.08 \mathrm{c}$ & $15.43 \mathrm{c}$ & $15.70 \mathrm{c}$ & $9.30 \mathrm{bc}$ & $10.74 \mathrm{c}$ & $43.80 \mathrm{c}$ & $45.80 \mathrm{c}$ \\
I $_{1}$ 100 \% Irrig. + OVW +Cy. Ba. & $2.80 \mathrm{a}$ & $2.91 \mathrm{a}$ & $30.50 \mathrm{a}$ & $30.93 \mathrm{a}$ & $13.83 \mathrm{a}$ & $14.43 \mathrm{a}$ & $62.47 \mathrm{a}$ & $73.70 \mathrm{a}$ \\
I $_{2} 75 \%$ Irrig. + OVW +Cy. Ba. & $2.10 \mathrm{~b}$ & $2.35 \mathrm{~b}$ & $20.10 \mathrm{~b}$ & $20.43 \mathrm{~b}$ & $9.83 \mathrm{~b}$ & $11.70 \mathrm{~b}$ & $55.73 \mathrm{~b}$ & $57.80 \mathrm{~b}$ \\
I $_{3} 50 \%$ Irrig. + OVW +Cy. Ba. & $1.73 \mathrm{c}$ & $1.86 \mathrm{~d}$ & $13.80 \mathrm{~d}$ & $14.67 \mathrm{~d}$ & $8.86 \mathrm{c}$ & $10.53 \mathrm{~d}$ & $42.30 \mathrm{~d}$ & $41.32 \mathrm{~d}$
\end{tabular}

OVW = olive vegetation water

Means having the same letter(s) within the same column are not significantly differ at the probability of $5 \%$ level according to Duncan's Multiple Range Test.

\section{6- Fruiting (fruit set and yield)}

Effect of different irrigation regime with Cyanobacteria and OVW on fruiting.

Data presented in Table (11) indicated that all the tested treatments except $50 \%$ irrigation increased significantly initial and final fruit set of Manzanillo olive trees as compared with control during both seasons. In this concern application of $100 \%$ irrigated plus Cyanobacteria with 24 liter/ tree of OVW presented the highest significant percentage of initial fruit set $(6,81$ and 6,78) and final fruit set( 4.78 and 5,54\% ) in both seasons, respectively. Concerning yield $(\mathrm{Kg} / \mathrm{tree})$ of Manzanillo olive trees, the results also revealed that using $100 \%$ irrigated plus Cyanobacteria with 24 liter/tree of OVW significantly improved the yield (23,70 and $34.20 \mathrm{~kg} /$ tree) as compared to control in both seasons. Respectively. The present results are in harmony with those of Di-Giovacchino et al., (2002) on olive and Altieri et al., (2008) on olive who reported that OVW land application 
promoted crop yield of olive trees. Also, Cyanobacteria + OVW liquid bio-fertilizer resulted from cultivating three cyanobacteria strains on $(1: 1)$ water diluted OVW has the average values of the $\mathrm{pH}(7.5), \mathrm{EC}\left(1.45 \mathrm{dS} . \mathrm{m}^{-1}\right)$, dry matter $\left(28.32\right.$ g. $\left.1^{-1}\right)$. COD $\left(2.2 \mathrm{~g} .1^{-1}\right)$ organic matter $(1.4$ g. $\left.1^{-1}\right)$ and total phenolic compounds $\left(0.27\right.$ g. $\left.1^{-1}\right)$ after 15 days of incubation process. These results reflected that Cyanobacteria + OVW could be recommended as liquid bio-fertilizer for fertigation. Fertigation is a highly recommended technique to apply both water and nutrient into crops at the same time and reduce water and nutrient losses; producing soluble fertilizers benefits plants, soil, humans, and the environment by improving soil fertility and crop growth, while reducing nutrient leaching into the ground water (Bres, 2009).

Table 11. Effect of different irrigation regime and OVW treated with Cyanobacteria on fruit set and yield of Manzanillo olive leaves during 2013 and2014 seasons

\begin{tabular}{lcccccc}
\hline \multirow{2}{*}{ Treatments } & \multicolumn{2}{c}{ Initial Fruit set( \%) } & \multicolumn{2}{c}{ Final Fruit set( \%) } & \multicolumn{2}{c}{ Yield (Kg/tree) } \\
& $\mathbf{2 0 1 3}$ & $\mathbf{2 0 1 4}$ & $\mathbf{2 0 1 3}$ & $\mathbf{2 0 1 4}$ & $\mathbf{2 0 1 3}$ & $\mathbf{2 0 1 4}$ \\
\hline Control (100 \%) & $4.28 \mathrm{~b}$ & $5.06 \mathrm{c}$ & $1.87 \mathrm{c}$ & $2.18 \mathrm{c}$ & $8.74 \mathrm{c}$ & $17.47 \mathrm{c}$ \\
$\mathrm{I}_{1} 100 \%$ Irrig. + OVW +Cy. Ba. & $6.81 \mathrm{a}$ & $6.78 \mathrm{a}$ & $4.78 \mathrm{a}$ & $5.54 \mathrm{a}$ & $23.70 \mathrm{a}$ & $34.20 \mathrm{a}$ \\
$\mathrm{I}_{2} 75 \%$ Irrig. + OVW +Cy. Ba. & $4.64 \mathrm{~b}$ & $6.43 \mathrm{~b}$ & $3.08 \mathrm{~b}$ & $4.03 \mathrm{~b}$ & $10.60 \mathrm{~b}$ & $27.90 \mathrm{~b}$ \\
I $_{3}$ 50 \% Irrig. + OVW +Cy. Ba. & $3.80 \mathrm{c}$ & $4.90 \mathrm{~d}$ & $1.54 \mathrm{~d}$ & $1.88 \mathrm{~d}$ & 6.43 & $11.23 \mathrm{~d}$
\end{tabular}

$\mathrm{I}=$ irrigation $\quad \mathrm{Cy} \cdot \mathrm{Ba}=$ Cyanobacteria $\quad \mathrm{OVW}=$ olive vegetation water

Means having the same letter(s) within the same column are not significantly differ at the probability of $5 \%$

level according to Duncan's Multiple Range Test

\section{7- Fruit quality.}

Effect of different irrigation regime and OVW with treated Cyanobacteria on fruit length, diameter and weight

The effect of tested treatments on fruit length, diameter, and fruit weight of Manzanillo olive trees is shown in Table (12). As for fruit length, control was the superior $(2.65 \mathrm{~cm})$ in the first season, while in the second one the superior values $(2.59 \mathrm{~cm})$ recorded with application of $50 \%$ irrigation plus Cyanobacteria with 48 liter/ tree of OVW.

Concerning, fruit diameter, control had treatment the highest value in the first $\operatorname{season}(2.30 \mathrm{~cm})$ while, in the second season the highest value with application $50 \%$ irrigation plus Cyanobacteria 48 liter/ tree of OVW (1.95 $\mathrm{cm})$. As for fruit weight, control treatment gave the heaviest weight $(6.02 \mathrm{a})$ in the first season, while in the second one the superior values (5.33) were recorded with application of $75 \%$ irrigation plus cyanobacteria 36 liter/ tree of OVW.

Table 12. Effect of different irrigation regime and OVW treated with Cyanobacteria on fruit length, fruit diameter and fruit weight of Manzanillo olive during 2013 and2014 seasons

\begin{tabular}{lcccccc}
\hline \multirow{2}{*}{ Treatments } & \multicolumn{2}{c}{ Fruit length $(\mathbf{c m})$} & \multicolumn{2}{c}{ Fruit diameter $(\mathbf{c m})$} & \multicolumn{2}{c}{ F. weight $(\mathbf{g})$} \\
& $\mathbf{2 0 1 3}$ & $\mathbf{2 0 1 4}$ & $\mathbf{2 0 1 3}$ & $\mathbf{2 0 1 4}$ & $\mathbf{2 0 1 3}$ & $\mathbf{2 0 1 4}$ \\
\hline Control (100 \%) Irrig. & $2.65 \mathrm{a}$ & $2.20 \mathrm{~d}$ & $2.30 \mathrm{a}$ & $1.90 \mathrm{~b}$ & $6.02 \mathrm{a}$ & $4.35 \mathrm{bc}$ \\
$\mathrm{I}_{1} 100 \%$ Irrig. + OVW +Cy. Ba. & $2.45 \mathrm{~b}$ & $2.26 \mathrm{c}$ & $2.00 \mathrm{c}$ & $1.90 \mathrm{~b}$ & $5.26 \mathrm{c}$ & $4.47 \mathrm{~b}$ \\
$\mathrm{I}_{2} 75 \%$ Irrig. + OVW +Cy. Ba. & $2.36 \mathrm{c}$ & $2.30 \mathrm{~b}$ & $2.00 \mathrm{c}$ & $1.80 \mathrm{c}$ & $5.51 \mathrm{~b}$ & $5.33 \mathrm{a}$ \\
$\mathrm{I}_{3} 50 \%$ Irrig. + OVW +Cy. Ba. & $2.24 \mathrm{~d}$ & $2.59 \mathrm{a}$ & $2.09 \mathrm{~b}$ & $1.95 \mathrm{a}$ & $5.23 \mathrm{c}$ & $4.20 \mathrm{c}$ \\
I= irrigation & Cy.Ba = Cyanobacteria & \multicolumn{2}{c}{ OVW = olive vegetation water } & \\
\hline
\end{tabular}

Means having the same letter(s) within the same column are not significantly differ at the probability of $5 \%$

level according to Duncan's Multiple Range Test.

\section{Stone length, diameter and weight:}

Data in Table (13) indicated that shows the effect of different irrigation regime and OVW with cyanobacteria on stone length, diameter and weight. As for stone length, $50 \%$ irrigation regime and OVW with Cyanobacteria has the highest values (1.64 and 1.80) in the first and second seasons, respectively. As for stone diameter, $50 \%$ irrigation regime and OVW with Cyanobacteria was the superior in the first season(0.99) while in the second one the superior values were recorded with the control. Regarding the weight, control gave the highest values (0stone.96,1.02) during 2013 and 2014 growing seasons, respectively. These results are nearly in the same line with these obtained by Haynes and Swift (1990) and Noval and Rezk (2009), Who reported that the length of organic wastes recycling when they are applied for soil in improving the soil physical properties such as densities, porosities, structure, aggregation, water retention and transmission, due to direct effect on retention water (hydrophilic mature) and indirect effect of the modification of the soil structure. Also, Laor et al. (2011) reported that soil microbial activity was generally by OVW application. 
Table 13. Effect of different irrigation regime and OVW treated with Cyanobacteria on stone length, stone diameter and stone weight of Manzanillo olive during 2013 and 2014 seasons

\begin{tabular}{lcccccc}
\hline \multirow{2}{*}{ Treatments } & \multicolumn{2}{c}{ Stone length $(\mathbf{c m})$} & \multicolumn{2}{c}{ Stone diameter $(\mathbf{c m})$} & \multicolumn{2}{c}{ Stone weight $(\mathbf{g})$} \\
& $\mathbf{2 0 1 3}$ & $\mathbf{2 0 1 4}$ & $\mathbf{2 0 1 3}$ & $\mathbf{2 0 1 4}$ & $\mathbf{2 0 1 3}$ & $\mathbf{2 0 1 4}$ \\
\hline Control (100 \%) Irrig. & $1.60 \mathrm{a}$ & $1.57 \mathrm{~b}$ & $0.98 \mathrm{a}$ & $0.99 \mathrm{a}$ & $0.96 \mathrm{a}$ & $1.02 \mathrm{a}$ \\
$\mathrm{I}_{1} 100 \%$ Irrig. + OVW +Cy. Ba. & $1.43 \mathrm{~b}$ & $1.50 \mathrm{c}$ & $0.87 \mathrm{c}$ & $0.92 \mathrm{~b}$ & $0.75 \mathrm{~d}$ & $0.78 \mathrm{c}$ \\
$\mathrm{I}_{2} 75 \%$ Irrig. + OVW +Cy. Ba. & $1.62 \mathrm{a}$ & $1.60 \mathrm{~b}$ & $0.94 \mathrm{~b}$ & $0.86 \mathrm{c}$ & $0.81 \mathrm{c}$ & $0.84 \mathrm{~b}$ \\
$\mathrm{I}_{3} 50 \%$ Irrig. + OVW +Cy. Ba. & $1.64 \mathrm{a}$ & $1.80 \mathrm{a}$ & $0.99 \mathrm{a}$ & $0.90 \mathrm{~b}$ & $0.92 \mathrm{~b}$ & $0.78 \mathrm{c}$
\end{tabular}

$$
\mathrm{I}=\text { irrigation } \quad \mathrm{Cy} \cdot \mathrm{Ba}=\mathrm{Cyanobacteria} \quad \mathrm{OVW}=\text { olive vegetation water }
$$

Means having the same letter(s) within the same column are not significantly differ at the probability of $5 \%$

level according to Duncan's Multiple Range Test.

Flesh weight, flesh/fruit weight \% and oil content:

Data in Table (14) revealed that control gave the heaviest flesh weight $(5.06 \mathrm{~g})$ in the first season, while in the second season the heaviest weight (4.49 g) with application of $75 \%$ irrigation with cyanobacteria 36 liter/ tree of OVW. As for flesh /fruit weight percentage, application of $100 \%$ irrigation with cyanobacteria 24 liter/ tree of OVW in the first season gave the highest percentage (84.78) while in the second one the highest percentage(86.37)recorded with application of $50 \%$ irrigated cyanobacteria with 48 liter/ tree of OVW. Oil content was significantly affected by application of 100 $\%$ irrigated cyanobacteria with 24 liter/ tree of OVW in both seasons. El-Hassani et al. (2010) pointed to an increase in oil content by $17 \%$ in comparison with control in response to application of olive mill waste water as an amendment for Menthaspicata L., but other worker report that, the oil content expressed as a percentage of dry weight, decreased significantly after agronomic application of OVW (Mechri et al., 2009).

Table 14. Effect of different irrigation regime and OVW treated with Cyanobacteria on flesh weight, flesh/fruits $\%$ and fruit oil content of Manzanillo olive during 2013 and 2014 seasons

\begin{tabular}{lcccccc}
\hline \multirow{2}{*}{ Treatments } & \multicolumn{2}{c}{ Flesh weight $(\mathbf{g})$} & \multicolumn{2}{c}{ Flesh/fruits $(\boldsymbol{\%})$} & \multicolumn{2}{c}{ Fruit oil content (\%) } \\
& $\mathbf{2 0 1 3}$ & $\mathbf{2 0 1 4}$ & $\mathbf{2 0 1 3}$ & $\mathbf{2 0 1 4}$ & $\mathbf{2 0 1 3}$ & $\mathbf{2 0 1 4}$ \\
\hline Control (100 \%) Irrig. & $5.06 \mathrm{a}$ & $3.33 \mathrm{~d}$ & $84.29 \mathrm{~b}$ & $76.62 \mathrm{~d}$ & $30.14 \mathrm{~b}$ & $32.08 \mathrm{~b}$ \\
$\mathrm{I}_{1}$ 100 \% Irrig. + OVW +Cy. Ba. & $4.51 \mathrm{c}$ & $3.69 \mathrm{~b}$ & $84.78 \mathrm{a}$ & $82.56 \mathrm{~b}$ & $35.91 \mathrm{a}$ & $37.85 \mathrm{a}$ \\
$\mathrm{I}_{2}$ 75 \% Irrig. + OVW +Cy. Ba. & $4.70 \mathrm{~b}$ & $4.49 \mathrm{a}$ & $84.34 \mathrm{~b}$ & $79.34 \mathrm{c}$ & $30.91 \mathrm{~b}$ & $31.43 \mathrm{~b}$ \\
I $_{3}$ 50 \% Irrig. + OVW +Cy. Ba. & $4.31 \mathrm{~d}$ & $3.42 \mathrm{c}$ & $83.57 \mathrm{c}$ & $86.37 \mathrm{a}$ & $30.72 \mathrm{~b}$ & $31.19 \mathrm{~b}$ \\
I= irrigation
\end{tabular}

$\mathrm{I}=$ irrigation $\mathrm{Cy} \cdot \mathrm{Ba}=\mathrm{Cyanobacteria}$
Means having the same letter(s) within the same column are not si

OVW $=$ olive vegetation water

Means having the same letter(s) within the same column are not significantly differ at the probability of $5 \%$

level according to Duncan's Multiple Range Test.

\section{8- Economic study}

Table (15) shows total yield of olive Manzanillo cultivars, in $\mathrm{Kg} / \mathrm{feddan}$ and total return in Egyptian pounds. Price/Kg was 3 Egyptian pounds in 2013 \& 2014 and water price/meter was 0.5 Egyptian pounds. Total operation cost included water costs plus costs of fertilizers, labors, pesticides and others. The net income of the irrigation level $3402.5 \mathrm{~m}^{3} /$ feddan applications on yield of Manzanillo olive trees achieved the highest net income during 2013 and 2014 seasons. It's recommended to apply this treatment to get the highest rate of economic

Table (15). Economic evaluation of Cyanobacteria and Olive Vegetation Water (Cyanobacteria+ OVW) on olive trees under different irrigation regime during 2013 and 2014

\begin{tabular}{|c|c|c|c|c|c|c|c|c|c|c|}
\hline 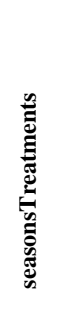 & 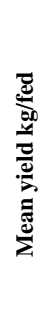 & 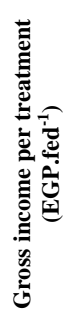 & 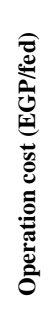 & 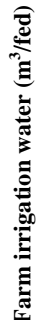 & 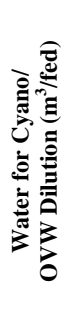 & 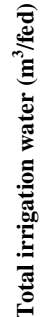 & 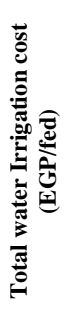 & & 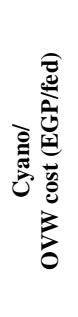 & 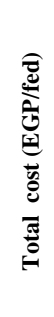 \\
\hline
\end{tabular}

\begin{tabular}{|c|c|c|c|c|c|c|c|c|c|c|c|c|c|c|}
\hline & 2013 & 2014 & 2013 & 2014 & \multicolumn{8}{|c|}{ Average for two seasons } & \multirow{2}{*}{$\frac{2013}{-2665}$} & \multirow{2}{*}{$\begin{array}{c}\mathbf{2 0 1 4} \\
170\end{array}$} \\
\hline Control (100\%) & 945 & 1890 & 2835 & 5670 & 3800 & 3400 & 0.00 & 3400 & 1700 & 0.00 & 0 & 5500 & & \\
\hline $\mathrm{I}_{1} 100 \%$ Irrig. + Cy OVW +Cy. Ba. & 2520 & 3570 & 7560 & 10710 & 3800 & 3400 & 1.26 & 3401 & 1701 & 1.26 & 126 & 5627 & 1933 & 5083 \\
\hline $\mathrm{I}_{2} 75 \%$ Irrig. OVW +Cy. Ba. & 1155 & 2940 & 3465 & 8820 & 3800 & 2550 & 1.68 & 2552 & 1276 & 1.68 & 189 & 5265 & -1800 & 3555 \\
\hline $\mathrm{I}_{3} 50 \%$ Irrig. + OVW +Cy. Ba. & 735 & 1260 & 2205 & 3780 & 3800 & 1700 & 2.52 & 1703 & 851 & 2.52 & 252 & 4903 & -2698 & -1123 \\
\hline $\begin{array}{l}* \text { Gross income }\left(\text { EGP.fed }^{-1}\right)=\mathbf{N} \\
* \text { Operation cost }\left(\text { EGP.fed }^{-1}\right)= \\
* \text { Sell Price of Cyano }+ \text { OVW } \\
* \text { Total cost }\left(\text { EGP.fed }{ }^{-1}\right)=\text { Oper } \\
* \text { Net return }\left(\text { EGP.fed }^{-1}\right)=\text { Gro }^{*}\end{array}$ & $\begin{array}{l}I=\text { irri } \\
\text { ean yie } \\
\text { ost of i } \\
\text { 0.1 EG } \\
\text { tion co } \\
\text { incom }\end{array}$ & $\begin{array}{l}\text { gation } \\
\text { d kg.fe } \\
\text { rigatio } \\
\text { P.L } \text {-1 }^{- \text {Tot }} \\
\text { t Tot }\end{array}$ & $\begin{array}{l}{ }^{1} \times \text { Sell } \\
\text { Labo }\end{array}$ & $\begin{array}{l}\text { Cy. } \\
\text { Price of } \\
\text { s, pestic }\end{array}$ & $\begin{array}{l}a=\text { Cya } \\
\text { olive fr } \\
\text { des an }\end{array}$ & $\begin{array}{l}\text { bacteri } \\
\text { ts (3.0 } \\
\text { thers }\end{array}$ & GP/K & $\mathrm{OVW}=$ & ive veg & tion $\mathrm{v}$ & & & & \\
\hline
\end{tabular}




\section{CONCLUSION}

The results of the experiment indicated that irrigation level $3402.5 \mathrm{~m}^{3} /$ feddan plus Olive Vegetation Water $(\mathrm{OVW})$ was the optimum water requirement for olive trees at Cairo-Alexandria desert road of Egypt, where this level of irrigation achieved the highest net profit in economic study.

\section{REFERENCES}

Adam, M. S. (1999). The promotive effect of cyanobacterium (Nostocmuscorum) on the growth of some crop plants. Acta Microbiological Polonuca, 48 (2): 2 136-171.

Altieri, R. and E. AQlessandro. (2008). Olive orchard with two experimental olive mill wastes mixtures: effects on soil organic carbon, plant growth and yield. Bioresource Technology. Vol. 99: 8390-8393.

Aly, E. A. (2005). Physiological studies on the effect of salt stress on some olive cultivators. Ph., D. Thesis, Fac. Agric., Benha Univ., Egypt.

Aly, M.H.A.; A.M. Abd El-All, Azza and S.M. Mostafa, Soha (2008). Enhancement of sugarbeet seed germination, plant growth, performance and biochemical compounds as contributed by algal extracellular products. J. Agric. Sci. Mansoura Univ., 33 (12): 8429-8448.

Amores-Sanchez, I.; M. C. Terrón-Orellana; A. E. González-Becerra and G. D. de Villegas, Tania (2015). Potential of microalgae and cyanobacteria in bioremediation of distillery waste waters. ICIDCA. Sobrelos Derivados de la Caña de Azúcar, 49 (1): 5870.

Annibale, D. A.; S.R. Stazi, V. Vinciguerra and G. G. Sermanni (2000). Oxirane-immobilized Lentinulaedoseslaccase: Stability and phenolics removal efficiency in olive mill wastewater. J. Biotechnol. 77:265-273.

Association of Official Agricultural Chemists (A.O.A.C.) (1995). Official Methods of Analysis. $15^{\text {th }} \mathrm{ed}$. Association of Official Analytical Chemists. Published by Washington, D. C., USA.

Bardi, L. and E. Malusa (2012). Drought and nutritional stresses in plant: alleviating role of rhizospheric microorganisms. In Abiotic Stress: New Research, N. Haryana and Punj (Eds). Nova Science publishers, Inc. Hauppauge, NY, USA.1-57.

Black, C.A.; D.D. Evans; L. E. Ensminger; G.L. White and F.E. Clarck (1982) .Methods of Soil Analysis Part 2.Agron.Inc. Madison. Wisc.

Box, J.D. (1983) Investigation of the Folin-Ciocalteau Phenol Reagent for the Determination of Polyphenolic Substances in Natural Waters. Water Research, 17: 511-522.

Bres, W. (2009). Estimation of nutrient losses from open fertigation systems to soil during horticultural plant cultivation. Polish J. Environ. Stud., 18(3): 341-345.

Brown, J. D. and D. Lilleland (1946). Rapid determination of potassium and sodium in plant material and soil extract by flame photometer. Proc. Amer. Soc. Hort. Sci. 48: 341.
Casa, R.; A. D Annibale; F. Pieruccetti; S. R. Stazi, G. G. Sermanni and B. Lo Casio (2003). Reuction of phenolic components in olive mill wastewater by an enzymatic treatment and its impact on drumwheat (Triticum durum Dasf.) geminability. Chemosphere, 50: 959-966.

Casida, L. E.; D.A. Klein and Santoro T. (1964). Soil dehydrogenase activity. Soil Sci., 98: 371-376.

Chapman, H.D. and P. F. Pratt (1961). Methods of Analysis for Soils, Plants and Waters. Division. Of. Agric. Sci. Univ. California, Berkeley, USA. PP:309.

Chartzoulakis, K.; G. Psarras; M. Moutsopoulou and E. Stefanoudaki (2010). Application of olive wastewater to cretan olive orchard: Effects on soil properties, plant performance and the environment. Agriculture Ecosystem and Environment, 138, 293-298.

Di Giovacchino, 1.; C. Basti; N. Costantini and G. Surricchio (2002). Olive vegetable water spreading and soil fertilization. Proc. $4^{\text {th }}$ IS on olive growing. Acta Hort., 586: 389-392.

El-Hadrami, A.; M. Belaqziz, M. El-Hassni, S. Hanifi, A. Abbad; R. Capasso; L. Gianfreda and I. El-Hadrami (2004). Physico- chemical characterization and effects of olive mill wastewater fertigation on the growth of some Mediterranean crops. J. of Agron. 3(4): 247-254.

El-Hassani, F.Z.; A. Zinedine; M. Alaoui; M. Merzouki and M. Benlemlih (2010). Use of olive mill wastewater as an organic amendment for Menthaspicata L. Industrial Crops \& Products, vol.32,3:343-348.

Fernandez J.E.; F. Moreno; F. Cabrera; J.L. Arrue and J. Martin-Aranda (1991). Drip irrigation, soil characteristics and the root distribution and root activity of olive trees. Plant and Soil. 133:239-251.

Fouad, M.M.; O.A. Kilany and M.E. El-Said (1992). Comparative studies on inflorescence emergence, fruit-set and yield of some olive cultivars under Giza conditions. Egypt. J. Apple. Sci., 7:630-644.

Gamba, C.; C. Piovanelli; R. Papini; B. Pezzarossa; L. Cecca-rini and E. Bonari (2005). Soil microbial characteristics and mineral nitrogen availability as affected by olive waste water applied to cultivated soil. Commun. Soil Sci. plant Anal. 36:937-950.

Garcia Barrionuevo, A..; E. Moreno; J. Quevedo-Sarmiento; J. Gonzalez Lopez and A. Ramos Cormenzana (1992). Effect pf waste waters from olive oil mills (alpechin) on Azotobacternitrogen fixation in soil. Soil Biol. Biochem, 24: 281-283.

Hardy, R.W.E., R.C. Burns and R.D. Holsten, (1973.) Application of the acetylene-ethylene assay for measurement of nitrogen fixation. Soil Biol. Biochem., 5: 47-81.

Haynes, R.J. and R.S. Swift (1990). Stability of soil aggregates in relation to organic constituents and soil water content. J. Soil Sci., 41: 73-83.

Heady, E.O. and J.L. Dillon (1961). Agricultural Production Functions. Iowa State University Press. Iowa State University Press, Iowa, U.S.A.

Ibrahim, S.; Y. Laor; M. Raviv and S. Medina (2007). Land spreading of olive mill wastewater: Effects on soil microbial activity and potential phytotoxicity. Chemosphere J., 66: 75-83. 
Jackson, M. L. (1973). Soil Chemical Analysis. PrenticeHall, Inc., N.J. Private Limited and New Delhi, India.

Kulk, M. M. (1995). The potential for using Cyanobacteria(blue-green algae) and algae in the biological control of plant pathogenic bacteria and fungi. European J. Plant Pathol., 101(6):585-599.

Lindsay W.1., Norvell W.A. (978). Development of a DTPA soil test for zinc, iron, manganese and copper. Soil Science Society of America, 42: 421-428.

Loar, Y.; I. Saadi; M. Raviv; S. Medina; D. Erez-Reifen and H. Eizenberg (2011). Land spreading of olive mill wastewater in Israel: Current Knowledge, practical experience, and future research needs. Israel Journal of Plant Sciences, 59: 39-51.

Lopez, R.; A. A. Martinez-Bordiu; E. Dupuy de lome; F. Cabrera and M. C. Sanchez (1996). Soil properties after application of olive oil mill wastewater. Fresenius Envir Bull. 5:49-54.

Lozano-Garcia, B. and L. Parras-Alcantara (2013). Shortterm effects of olive mill by-products, total $\mathrm{N}, \mathrm{C}: \mathrm{N}$ ratio and stratification rations in a Mediterranean olive grove. Agriculture, Ecosystems \& Environ., 165:68-73.

Magdich, S.; J. Raja; R. Bechir-Ben and B. Makki (2012). A yearly spraying of olive mill wastewater on agricultural soil over six successive years: Impact of different application rates on olive production, phenol compounds, phytotoxicity and microbial counts. Science of the Total Environment, 430: 209-216.

Mahmoud, M.; M. Janssen; S. Peth; R. Horn and B. Lennartz (2012) Long-Term Impact of Irrigation with Olive Mill Wastewater on Aggregate Properties in the Top Soil. Soil and Tillage Research, 124, 24-31. http:// dx. doi. org/ 10.1016/ j.still.2012.04.002

Mechri, B.; A. Echbili; M. Issaoui; M. Braham; M. S. Ben elhadj and M. Hammami (2007). Short time effects in soil microbial community following agronomic application of olive mill wastewaters in a field of olive trees, Appl. Soil Ecol., 36:216-223.

Mechri, B.; M. Issaoui; A. Echbili; H. Chehab; M. Braham and M. Hammami (2009). Olive orchard amended with olive mill wastewater: Effects on olive fruit and olive quality. Journal of Hazardous materials, 172: 1544-1550.

Mekki A., A. Dhouib and S. Sayadi (2006). Changes in microbial and soil properties following amendment with treated and untreated olive mill wastewater. Microbiological Research, 161: 93-101.

Mofeed, A. S. (2002). Effect of picking date on flowering and fruiting of olive trees. M.Sc. Thesis, Faculty of Agriculture, Cairo University. Egypt.

Mohawesh, O.; M. Mahmoud; M. Janseen and B. Lennartz (2014). Effects of irrigation with olive mill wastewater on soil hydraulic and solute transport properties. Int. J. Environ. Sci. Technol., 11: 927-934.

Montemurro, F.; D. Mariangela; V. Carolina and F. Donato (2011). Potential use of olive mill wastewater as amendment: Crops yield and soil. properties assessment. communications in soil Science \& Plant Analysis, 42:2594-26 03.
Mostafa, S.M. Soha; A. Tantawy, Eman; A.H. El Gamal Manal and A. Kh. Abd El-Halim (2011). Effect of cyano- and endophytic-bacteria on wheat productivity under nitrogen limitation or irrigation regime in calcareous soil. N. Egypt. J. Microbiol, September, 30:210-241.

Murphy, J. and J. P. Riely (1962). A modified single dilution method for determination of phosphate in natural water. Ann. Chemi. Acta, 27:p:31-36.

Noval, O.A. and Al. Rezk (2009). Role of fertilization in improving quality of some agricultural crops. International J. Acd. Res., 1:59-65.

Olsen S.R.; C.V. Cole; F.S. Watanabe and L.A. Dean (1954). Estimation of phosphorus in soil by extraction with sodium bicarbonate. US Dept Agric. 939:1-19.

Page, A. L.; R. H. Miller and D. R. Keeny (1982). Methods of Soil Analysis. Part 2. Chemical and Microbiological Properties. $2^{\text {nd }}$ Edition. Madison, Wisconsin, USA.

Parades, C.; J. Cegarra; A. Roig; M.A. Sanchez. and M.P. Bernal (1999). Characterization of olive-mill maste mater (alpecchin) and its sludge for agricultural purposes. Bio-Resource Technology, 67: 111-115.

Piotrowska, A., G.; R. M. Antonietta and G. Liliana (2006). Short-term effects of olive mill waste water (OMW) on chemical and biochemical properties of a semiarid Mediterranean soil. Soil Biology \& Biochemistry. 38:600-610.

Piper, C.S. (1950). Soil and Plant Analysis. Int. Sci. Publ., New York, P. 368.

Piperidou, C.I.; I. Constantina; C. I. Chaidou; C.D. Stalikas; K. Soulti, G. A. Pilidis and C. Balis (2000). Bioremediation of olive oil mill wastewater: chemical alterations induced by Azotobacter vinelandii. J. Agri. Food Chem., 48:1941-1948.

Pregl, F. (1945). Quantitative organic micro-analysis. $4^{\text {th }}$ Ed, and A. Churchill. LTD. London. 126-129.

Rippka R.; J. Deruelles; J.B. Waterburg; M. Herdman and R.Y. Stanier (1979). Generic assignments, strain histories and properties of pure cultures of cyanobacteria. J. Gen Microbial 111: 1-16.

Saber, S. M. (1993). The use of multi strain biofertilizer in agriculture. Theory and practice. Proc. Sixth International Symposium on Nitrogen Fixation with Non-Legumes, Ismailia, Egypt, p. 61.

Sahu D.; I. Priyadarshani and B. Rath (2012). Cyanobacteria - as potential bio-fertilizer. CIB Tech Journal of Microbiology, 1 (2-3):20-26.

SAS (1994). SAS Statistics program, Version $6.4^{\text {th }}$ ed. SAA Inst., Cary, NT.

Shereen, A. Shaheen; A. A. El-Taweel and A. Al-Khateeb (2011). Effect of using olive vegetative water on growth, flowering and yield of Manzanillo olive trees. Journal of American Science, 7(9):501-510.

Skerget M; P. Kotnik; M. Hadolin; A.R. Hras; M. Simoni and Z. Knez (2005). Phenols, proanthocyanidins, flavones and flavonols in some plant materials and their antioxidant activities. Food Chem. 89, 191-198.

Snedecor, G. W. and W. G. Cochran (1980). Statistical Methods. $7^{\text {th }}$ ed. Iowa State Univ. Press, Ames, Iowa, USA PP. 507. 


\section{El-Taweel, A. A.A et al.}

Van Schouwonburg, J.Ch. (1968). International report of soil and plant analysis, Lab. of Soils \& Fertilizers Agric. Univ. Wageningen, Netherlands.

Van-Camp, L.; B. A. R. Gentile; R. J. A. Jones; L. Montanarella; C. Olazabal and S.K. Selvaradjou (2004). Reports of the technical working groups established under the thematic strategy for soil protection. EUR $21319 \mathrm{EN} / 3$, (p.872). Office for official Publications of the European Communities, Luxembourg.
Vonshak, A. (1986). Laboratory techniques for the cultivation of microalgae. In: Richmond A (ed), CRC handbook of microalgal mass culture pp. 117-145 CRC press, Boca Raton, Florida, USA.

Zarrouk C. (1966). Contribution a letude d, unecyanobacteria.Infuence de divers facteurs physiques etchimiquessur la croissanceet la photosynthese de Paris, France

\section{تأثثر مقتنات الري المختلفة والماء الخضري المعالج بالسيانو بكتريا على خواص التربة الكيميائية والنمو والمحصول وجودة الثمار لأشجار الزيتون.

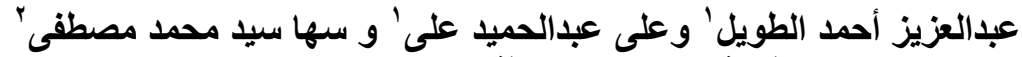

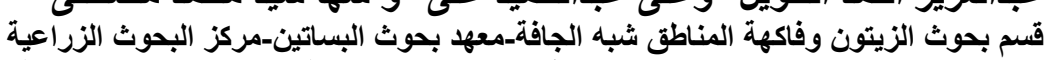

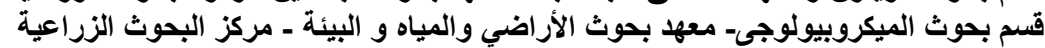

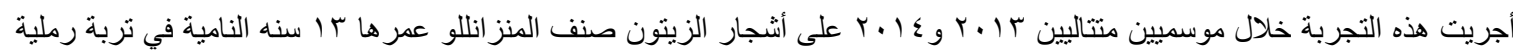

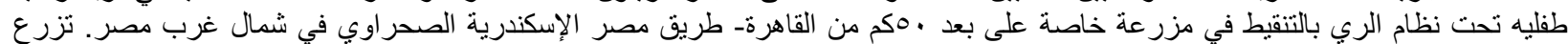

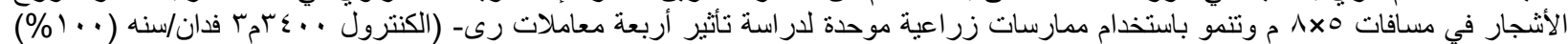

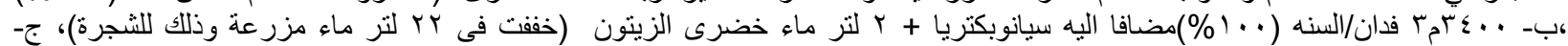

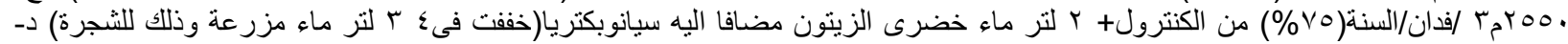

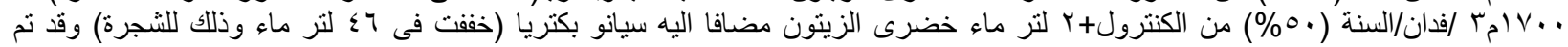

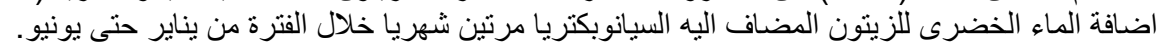

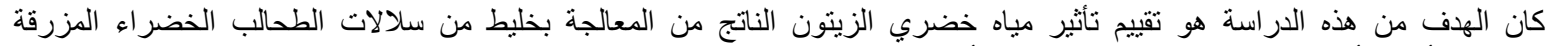

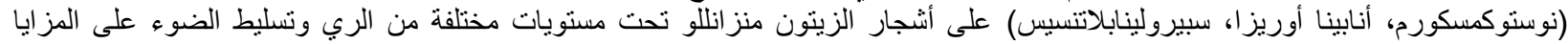

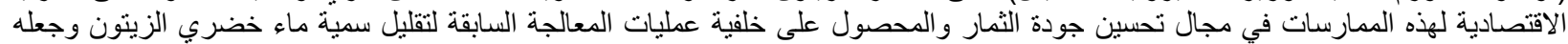

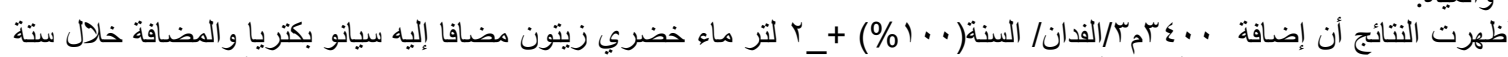
مقبو لا للتربة و المياه.

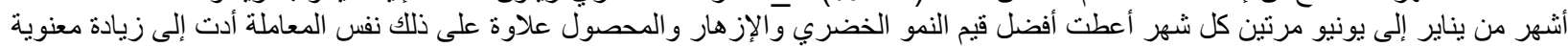

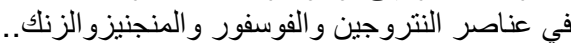
وهذه هي المعاملة التي يمكن أن نوصى بها تحت ظرورف هذه الدراسة والظروف المشابهة و هذا ما أكتنه دراسة الجدوى الاقتصادية. 